\title{
ENERGY PROPERTIES OF SUNFLOWER SEED HUSK AS INDUSTRIAL EXTRUSION RESIDUE
}

\author{
Grzegorz Maj, Paweł Krzaczek, Andrzej Kuranc, Wiesław Piekarski \\ Department of Power Engineering and Transportation, University of Life Sciences in Lublin \\ *Corresponding author: grzegorz.maj@up.lublin.pl
}

\begin{tabular}{|c|c|}
\hline ARTICLE INFO & ABSTRACT \\
\hline $\begin{array}{l}\text { Article history: } \\
\text { Received: August } 2016 \\
\text { Received in the revised form: } \\
\text { September } 2016 \\
\text { Accepted: October } 2016 \\
\end{array}$ & $\begin{array}{l}\text { The paper presents possibilities of using by - products of the agri-food } \\
\text { sector, in the form of sunflower husks, for energy purposes. Physical } \\
\text { and chemical properties in the form of heat of combustion, calorific } \\
\text { value for three moisture levels and ash content for two temperatures of } \\
\text { combustion were determined and the carbon content (C), hydrogen }\end{array}$ \\
\hline $\begin{array}{l}\text { Key words: } \\
\text { biomass, } \\
\text { heat of combustion, } \\
\text { calorific value, } \\
C, H, N \text { content }\end{array}$ & $\begin{array}{l}\text { content }(\mathrm{H}) \text { and nitrogen content }(\mathrm{N}) \text { were calculated pursuant to the } \\
\text { PN-EN } 15104 \text { standard. Analysis of the heat of combustion and } \\
\text { calorific value proved good energy properties of the investigated } \\
\text { biomass. For the moisture level of } 9 \%, 16 \%, 32 \% \text { the heat of combus- } \\
\text { tion was respectively } 19.44 \mathrm{MJ} \cdot \mathrm{kg}^{-1}, 17.94 \mathrm{MJ} \cdot \mathrm{kg}^{-1}, 15.03 \mathrm{MJ} \cdot \mathrm{kg}^{-1} \text {, and } \\
\text { the calorific value } 18.09 \mathrm{MJ} \cdot \mathrm{kg}^{-1}, 16.28 \mathrm{MJ} \cdot \mathrm{kg}^{-1}, 13.16 \mathrm{MJ} \cdot \mathrm{kg}^{-1} \text {. The } \\
\text { average ash content of the investigated biomass for the combustion } \\
\text { temperature of } 600^{\circ} \mathrm{C} \text { and } 815^{\circ} \mathrm{C} \text { was respectively } 2.12 \% \text { and } 2.04 \text {. In } \\
\text { the analyzed biomass the nitrogen content was determined at the level } \\
\text { of } 1.57 \% \text {, carbon of } 43.87 \% \text { and hydrogen of } 6.29 \% \text {. }\end{array}$ \\
\hline
\end{tabular}

\section{Introduction}

Energy production from biomass is the oldest and the simplest method of satisfying the energy needs. This source is considered as one of the solutions for the problems related to reduction of harmful emissions to the environment during energy production. Taking into consideration that the total amount of the produced biomass exceeds tenfold the present demand and the use of its potential is low, the amount of the potential energy, which may be obtained from this raw material, is considerable and for Poland it is $895 \mathrm{PJ}^{-y e a r}{ }^{-1}$ (Abbasi, Abbasi, 2010; Jasiulewicz, 2014).

Numerous research, analyses and reports concerning the power industry indicate a high probability of an energy crisis. Analysis of data shows differences concerning only the period of its occurrence, which is expected to take place within the next 15-25 years (Kopetz et al., 2007; Lapillonne, 2007; Roszkowski, 2008).

When we earmark biomass for energy purposes, we should analyze it thoroughly in the context of its basic food use. A solution for this problem consists in the need to increase residues and by-products from agriculture, agri-food sector and forestry in the amount of biomass used for energy purposes, both professional and dispersed. Presently in the power energy industry a small part of organic waste is used as a source of energy. 
Analysis of thermal distribution and combustion processes of organic waste as renewable and environmentally friendly energy sources was described in many research (Gañán et al., 2006; González et al., 2003; Yin et al., 2008; Żabiński et al., 2015). So far, inter alia, products and agricultural and agri-food waste, herbal waste in the form of grapevine sprouts, cherry and olive stones, coffee residues, plant waste from tomatoes, almond and nut husks and coconut husks, lavender and sage, which were used as an energy source, have been analyzed (Gañán et al., 2006; González et al., 2003; Yin et al., 2008; Encinar et al., 2008; Ghani et al., 2009; Haykiri Acma and Yaman, 2008; Żabiński et al., 2015). With regard to the above the authors of the paper paid attention to the process of formation of sunflower oil and more strictly to the post-production residues in the form of sunflower seed husks.

During an industrial production of plant oil from sunflower seeds a considerable amount of husk remains, which may constitute to $20 \%$ of the weight of processed seeds and may serve as energy raw material (Bartosiewicz-Burczy et al., 2010). In Poland, due to unfavorable climatic conditions cultivation of sunflower is carried out to a small extent. Therefore, majority of the raw material is imported. According to the Polish Association of Oil Industry in $2009452000 \mathrm{Mg}$ of sunflower seeds were imported with the total value of PLN 215 million and majority came from Ukraine and Hungary. On the other hand, in 2014 the import of sunflower seeds increased to $490000 \mathrm{Mg}$ (Bartosiewicz-Burczy et al., 2010; Main Statistical Office, 2015).

With regard to the above presented essential potential of this organic production residue, we assumed analysis of its energy purposes and possibility of use of a possible source of renewable energy as the aim of the paper.

\section{Material and methods}

We obtained the research material from a processing plant, which processed sunflower seeds into oil in Gyor town in Hungary and the tests were carried out in laboratories of the Department of Power Energy and Transport Means of the University of Life Sciences in Lublin. Husks were milled in a laboratory mill IKA A 11. The heat of combustion and calorific value were determined pursuant to PL-EN 14918 standard with the use of a calorimeter LECO AC 600. The energy value was determined for 3 moisture levels i.e. 9\%, $16 \%$ and $32 \%$ in 10 iterations as a reference to the moisture content in material in the technological process (9\%) and possible conditions of storage and transport (16\% and 32\%). The calorific value was calculated with the use of a dedicated computer application by entering data concerning moisture and hydrogen content in the investigated material which uses the formula from PN-EN standard 14918 (1) for calculations of calorific value:

$$
Q_{i a}=Q_{s a}-24.43 \cdot\left(W_{a}+8.94 \cdot H^{a}\right)
$$

where:

$Q_{i a} \quad$ - calorific value in the analytical state, $\left(\mathrm{J} \cdot \mathrm{g}^{-1}\right)$

$Q_{s a} \quad$ - heat of combustion in the analytical state, $\left(\mathrm{J}^{-1} \mathrm{~g}^{-1}\right)$

24.43 - heat of water vaporization in the temperature of $25^{\circ} \mathrm{C}$ corresponding to $1 \%$ of water in fuel,

$8.94-$ calculation coefficient of hydrogen content into water, $\left(\mathrm{J} \cdot \mathrm{g}^{-1}\right)$ 
Energy properties...

$$
\begin{array}{ll}
H^{a} & \text { - hydrogen content in the analytical sample (\%) } \\
W_{a} & \text { - analytical moisture of fuel sample, (\%) }
\end{array}
$$

The ash content was calculated pursuant to PN-EN 14775 standard and moisture content based on PN-EN 14774-1 standard based on the loss of mass remaining after heating the material in the strictly controlled conditions in the air atmosphere in 12 samples. We used LECO TGA 701 thermogravimeter for both calculations. Analytical moisture of the investigated sample of material was calculated by the program according to PN-EN 14774-1 standard according to the relation (2):

$$
W_{a}=\frac{\left(m_{1}-m_{2}\right)}{\left(m_{1}-m_{3}\right)} \cdot 100 \%
$$

where:

$W_{a}$ - analytical moisture, (\%)

$m_{1}$ - mass of a vessel with weighed amount of material before drying, (g)

$m_{2}$ - mass of a vessel with weighed amount of material after drying, (g)

$m_{3}$ - mass of an empty vessel, (g)

Ash content in the analytical sample with moisture of $9 \%$ was calculated by the dedicated program pursuant to PN-EN 14775 standard according to the relation (3). Samples for research were combusted in the temperature of 600 and $815^{\circ} \mathrm{C}$.

$$
A^{a}=\frac{\left(m_{3}-m_{1}\right)}{\left(m_{2}-m_{1}\right)} \cdot 100 \%
$$

where:

$$
\begin{array}{ll}
A^{a} & \text { - ash content in the analytical sample, (\%) } \\
m_{1} & \text { - mass of roasted vessel, (g) } \\
m_{2} & \text { - mass of a vessel with weighted amount of material, (g) } \\
m_{3} & \text { - mass of a vessel with ash, (g) }
\end{array}
$$

Calculations of the total carbon content $(\mathrm{C})$, hydrogen $(\mathrm{H})$ and nitrogen $(\mathrm{N})$ were carried out according to PN-EN 15104 standard. The analysis was made with the use of CHN628 analyzer by LECO company. The process of carbon content, hydrogen and nitrogen calculation was carried out in the temperature of $950^{\circ} \mathrm{C}$ in the atmosphere of clean oxygen.

We subjected the obtained results to statistical analysis, which was carried out with the use of STATISTICA v. 10. Regularity of distribution of the analyzed properties was verified with Shapiro-Wilk's test. Uniformity of variance was checked with the use of Bartlett's test. We assessed the moisture impact on the heat of combustion and calorific value with the use of the univariate analysis of variance ANOVA. Moreover, significance of differences in groups was checked with Tukey's test. The impact of combustion temperature on the ash content was assessed with the use of a non-parametric U Mann - Whitney test for independent groups. All statistical analyses were carried out with the assumed level of significance of $\alpha=0.05$. 


\section{Results and discussion}

Bartlett's test proved that there is no reason to reject the hypothesis on the equivalence of variance for data concerning the heat of combustion $(\mathrm{BT}=4.76$ at a critical level of significance $\mathrm{p}=0.093$ and the calorific value $(\mathrm{BT}=4.75$ at the critical level of significance $\mathrm{p}=0.093)$. Statistical analysis proved that the average heat of combustion depends significantly on the moisture $(\mathrm{F}=1031.2$ at the critical level of significance $\mathrm{p}=0.00)$. Analysis for the calorific value demonstrated similar results $(\mathrm{F}=1292.2$ at the critical level of significance $\mathrm{p}=0.00$ ). The presented results of analysis of variance prove that the average heat of combustion significantly depends on moisture.

For the degree of significance $\alpha=0.05$ the results show significant variance between each of the compared groups (Table. 1). The analysis proved that with regard to the level of raw material moisture, the results for both heat of combustion and the calorific value differ considerably. Based on the Tukey's test it was confirmed that the energy value of raw material depends mainly on moisture.

Table 1.

Results of the statistical analysis of heat of combustion and calorific value (SD - standard deviation)

\begin{tabular}{lcc}
\hline $\begin{array}{l}\text { Moisture } \\
(\%)\end{array}$ & $\begin{array}{c}\text { Average heat of combustion } \pm \text { SD } \\
\left(\mathrm{J} \cdot \mathrm{g}^{-1}\right)\end{array}$ & $\begin{array}{c}\text { Average calorific value } \pm \text { SD } \\
\left(\mathrm{J} \cdot \mathrm{g}^{-1}\right)\end{array}$ \\
\hline 32.0 & $15002^{\mathrm{a}} \pm 305.04$ & $13138^{\mathrm{a}} \pm 292.72$ \\
16.0 & $17908^{\mathrm{b}} \pm 141.33$ & $16270^{\mathrm{b}} \pm 135.62$ \\
9.0 & $19560^{\mathrm{c}} \pm 214.92$ & $18003^{\mathrm{c}} \pm 206.45$ \\
\hline a, b, c Significant difference at the level of significance of $\alpha=0.05$
\end{tabular}

The highest values of the heat of combustion and the calorific value of the investigated raw material in the analysis were reported at the moisture of $9 \%$. They were within 19.25-19.87 MJ kg-1 for the heat of combustion while for the calorific value they were 17.70-18.31 MJ $\mathrm{kg}^{-1}$.

For the moisture of $16 \%$ and $32 \%$ the heat of combustion was within 17.66-18.20 $\mathrm{MJ} \cdot \mathrm{kg}^{-1}$ and $14.52-15.49 \mathrm{MJ} \cdot \mathrm{kg}^{-1}$. While the calorific value was respectively within $16.01-$ 16.54 $\mathrm{MJ} \cdot \mathrm{kg}^{-1}$ and $12.66-13.60 \mathrm{MJ} \cdot \mathrm{kg}^{-1}$

Analysis of results proves a dropping trend for the data concerning the heat of combustion and the calorific value along with the content of moisture in the investigated material. Analysis of the literature data concerning the heat of combustion and the calorific value for the sunflower husk proves that the obtained values are similar only for $9 \%$ of the material moisture. Energy parameters in the literature for the investigated biomass are within 15.94-17.37 MJ. kg-1 for the heat of combustion and $18.01-18.49 \mathrm{MJ} \cdot \mathrm{kg}^{-1}$ for the calorific value which indicates that the data obtained in the research for moisture of $16 \%$ and $32 \%$ are considerably lower (Król et al., 2010; Kułażyński et al., 2015; Kosowska-Golachowska et al., 2016). Thus, for the energy purposes husks must be kept in the optimal moisture level.

However, it should be emphasized that sunflower husks as residues after the industrial processes have low natural moisture and only for the needs of the research were taken phys- 
Energy properties...

ically to higher levels of moisture. Therefore, for energy assessment of raw material and the possibility of its later use one should take into consideration the results concerning the research for the lowest moisture, i.e. 9\%.

Results of determination of the ash content were also subjected to statistical analysis with a non-parametric method i.e. with U Mann- Whitney test for independent groups (Table 2) in order to evaluate the significance of variability between the results of ash content determination at combustion in the temperature of 600 and $815^{\circ} \mathrm{C}$.

Table 2.

U Mann-Whitney test results

\begin{tabular}{lccccccc}
\hline Variable & $\begin{array}{c}\text { Sum of } \\
\text { Ranks } \\
\text { T600 }\end{array}$ & $\begin{array}{c}\text { Sum of } \\
\text { Ranks } \\
\text { T815 }\end{array}$ & U & Z & p & $\begin{array}{c}\text { N } \\
\text { T600 }\end{array}$ & $\begin{array}{c}\text { N } \\
\text { T815 }\end{array}$ \\
\hline Ash content & 168.50 & 131.50 & 53.50 & 1.04 & 0.29 & 12 & 12 \\
\hline
\end{tabular}

Based on the test which was carried out one may state that there is no statistically significant differences in the ash content between the compared groups for two values of the temperature of combustion. It means that the level of temperature does not impact considerably the amount of ash obtained after combustion of biomass.

Results of determination of the ash content for the temperature of combustion of $600^{\circ} \mathrm{C}$ were within $1.9-2.3 \%$. While, the amount of ash obtained after combustion of sunflower husks in the temperature of $815^{\circ} \mathrm{C}$ was $1.8-2.3 \%$ (Fig. 1).

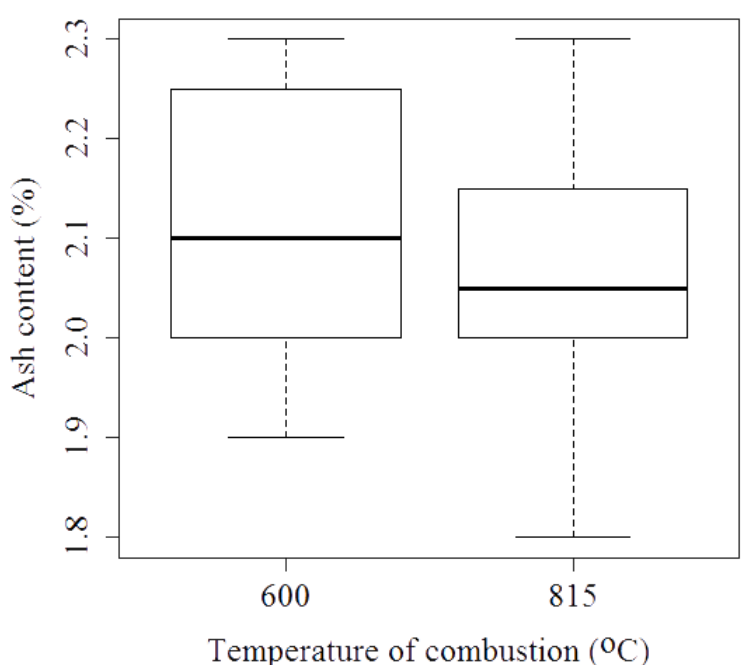

Figure 1. List of results of ash content calculation for two analyzed values of combustion temperatures 
For the temperature of combustion of $600^{\circ} \mathrm{C}$ the average percentage ash content was $2.12 \%$ while for the temperature of $815^{\circ} \mathrm{C}-2.04 \%$. It means that the difference between the obtained average results from the ash content test for two temperatures was less than 0.1 of the percentage point.

Data concerning the ash content in the combusted organic residues should help to determine possibilities of use of this type of biomass for the process of co-firing with coal or direct combustion. A comparison of the obtained results of the ash content from the combusted sunflower husk (at the average 2.1\%) with available data in the literature (Kowalczyk-Juśko, 2009), according to which the ash content from biomass from popular energy plants is within $2.5-3.6 \%$, is satisfactory.

The elementary analysis proved that a sunflower husk has a coal content at the level of $43.87 \%$, hydrogen $-6.29 \%$ and nitrogen $-1.75 \%$. The elementary analysis also proved that the coal content in biomass in the form of a husk is considerably lower than in the hard coal (Fig. 2).

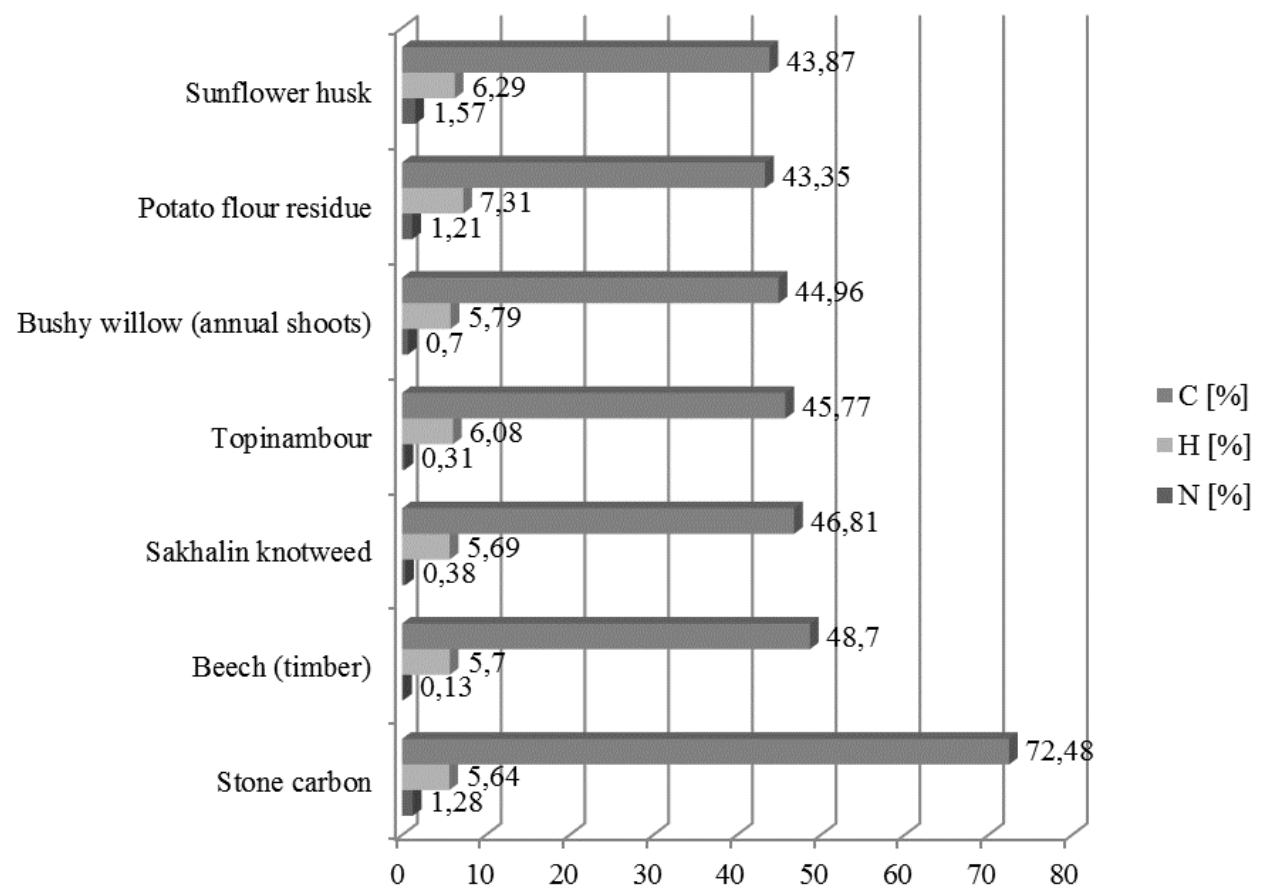

(author's own research based on Poskrobko et al., 2009; Komorowicz et al.., 2009; Golec, 2004)

Figure 2. Elementary composition of the selected energy raw material including sunflower husk

The highest content of elementary carbon is in case of hard coal, then oak timber and biomass from energy plants. The content of this element in a sunflower husk is slightly lower, however, it is close to the content of the remaining energy raw materials. The high- 
est, percentage amount of hydrogen is in case of potato flour and then the sunflower husk. Participation of nitrogen in the analyzed raw materials is the highest in case of potato flour and hard coal residue. The most favorable lowest content of these elements is in case of energy plants. The sunflower husk in comparison to energy materials has a similar elementary composition (Poskrobko et al., 2009; Komorowicz et al., 2009; Golec, 2004).

Literature data concerning the sunflower husk indicate that the coal content is within 47.61-51.66\%, nitrogen 1.27-3.23\% and hydrogen 5.42-6.20\% (Król et al., 2010; Kratofil et al., 2014; Kosowska-Golachowska et al., 2016). Comparison of the obtained research results allows a statement that the obtained results are comparable thereto and prove good physical and chemical properties of the investigated biomass.

\section{Conclusions}

Tests and analyses allowed making the following conclusions:

1. Sunflower husks as production residues after oil extrusion have low moisture (9\%) which eliminates the need to dry raw material before possible combustion.

2. Good thermal properties defined through calorific value (average value is $18 \mathrm{MJ} \cdot \mathrm{kg}^{-1}$ ) prove that sunflower husk constitutes an energy potential and may become an important energy source.

3. Agri-food residues in the form of sunflower husks have low ash content (ca. 2.1\%) and in comparison to the results of similar research for other energy raw materials (among popular plants the percentage ash content is 2.5-3.6\%) the result is considered as highly satisfactory.

\section{References}

Abbasi, T., Abbasi, S.A. (2010). Biomass energy and the environmental impacts associated with its production and utilization. Renewable and Sustainable Energy Reviews, 14, 919-937.

Bartosiewicz-Burczy, H., Mirowski, T., Kalawa, W., Sajdak, W. (2010). Study on Biomass Trade in Poland - Fostering the Sustainable Usage of Renewable Energy Sources in Central Europe Putting Biomass into Action. WP 4.2.4, IEN, Report of Project 4Biomass (www.4biomass.eu).

Encinar, J., Gonzalez, J., Martinez, G. (2008). Energetic use of the tomato plant waste, Fuel Processing Technology, 89, 1193-1200.

Gañán, J., Al-Kassir Abdulla, A., Cuerda Correa, E., Macias-Garcia, A. (2006). Energetic exploitation of vine shoot by gasification processes. A preliminary study. Fuel Processing Technology, 87, 891-897.

Ghani, W., Alias, A., Savory, R., Cliffe, K. (2009). Co-combustion of agricultural residues with coal in a fluidised bed combustor, Waste Management, 29, 767-773.

Golec T. (2004). Współspalanie biomasy w kotłach energetycznych. Energetyka, 7-8, 437-445.

González, J., Encinar, J., Canito, J., Sabio, E., Chacon, M. (2003). Pyrolysis of cherry stones: energy uses of the different fractions and kinetic study. Journal of Analytical and Applied Pyrolysis, 67, 165-190.

GUS. (2015). Rolnictwo w 2014 roku. Warszawa, ISSN 1507-9724.

Haykiri Acma, H., Yaman, S. (2008). Effect of co-combustion on the burnout of lignite/biomass blends: a Turkish case study. Waste Managment, 28, 2077-2084. 
Jasiulewicz, M. (2014). Potencjał energetyczny biomasy rolniczej w aspekcie realizacji przez Polskę Narodowego Celu Wskaźnikowego OZE i dyrektyw UE w 2020 roku. Roczniki Naukowe Stowarzyszenia Ekonomistów Rolnictwa i Agrobiznesu, 16(1), 70-76.

Komorowicz, M., Wróblewska, H., Pawłowski, J. (2009). Skład chemiczny i właściwości energetyczne biomasy z wybranych surowców odnawialnych. Ochrona Środowiska i Zasobów Naturalnych, 40, 402-410.

Kopetz, H., Jossart, J. M., Ragossnicg, H., Metschina, C. (2007). European Biomass Statistics 2007. AEBIOM. Brussels, 73.

Kosowska-Golachowska, M., Wolski, K., Gajewski, W., Kijo-Kleczkowska, A., Musiał, T., Środa, K. (2016). Spalanie biomasy agro i leśnej w cyrkulacyjnej warstwie fluidalnej. Rynek Energii, 3(124), 90-99.

Kowalczyk-Juśko, A. (2009). Popiół z różnych roślin energetycznych. Proceedings of ECOpole, Vol. 3, 1, 159-164.

Kratofil, M., Zarzycki, R., Kobyłecki, R., Bis, Z. (2014). Badania procesu toryfikacji biomasy. Polityka Energetyczna, 4(17), 137-146.

Król, D., Łach, J., Poskrobko, S. (2010). O niektórych problemach związanych z wykorzystaniem biomasy nieleśnej w energetyce. Energetyka, 1(667), 53-62.

Kułażyński, M., Kaczmarczyk, J., Świątek, Ł., Pstrowska, K., Jabłoński, S., Łukaszewicz, M. (2015). Problemy technologiczne występujące podczas realizacji procesu współspalania węgla brunatnego z biomasą. Logistyka, 5, CD 1, 277-282.

Lapillonne, B. (2007). Energy efficiency: Striking the Balance the energy Future in an Interdependent World. World Roma 12-15 November 2007 Roma.

Poskrobko, S., Łach, J., Król, D. (2009). Badanie podstawowych właściwości paliwowych wybranych odpadów przemysłowych i paliw formowanych z odpadów. Energetyka, 3, 633-640.

Roszkowski, A. (2008). Energia a rolnictwo (kryzys energetyczny-efektywność-rolnictwo). Inżynieria Rolnicza, 4(102), 25-36.

Yin, C., Rosendahl, L., Kaer, S. (2008). Grate-firing of biomass for heat and power production, Progress in Energy and Combustion Science, 34, 725-754.

Żabiński, A., Sadowska, U., Wcisło, G. (2015). Możliwości wykorzystania biomasy odpadowej z produkcji zielarskiej na cele energetyczne. Inżynieria Rolnicza, 4(156), 139-145.

\section{WLAŚCIWOŚCI ENERGETYCZNE LUSKI NASION SLONECZNIKA JAKO POZOSTALOŚCI Z TŁOCZENIA PRZEMYSŁOWEGO}

Streszczenie. W pracy przedstawiono możliwości wykorzystania produktów ubocznych sektora rolno-spożywczego w postaci łuski słonecznika z przeznaczeniem na cele energetyczne. Dla badanego surowca wyznaczono właściwości fizykochemiczne w postaci ciepła spalania, wartości opałowej dla trzech wilgotności i zawartości popiołu dla dwóch temperatur spalania oraz oznaczono zawartość węgla (C), wodoru (H) i azotu (N) zgodnie z normą PN-EN 15104. Analiza ciepła spalania i wartości opałowej wykazała dobre właściwości energetyczne badanej biomasy. Dla wilgotności $9 \%, 16 \%$, $32 \%$ ciepło spalania wyniosło odpowiednio $19,44 \mathrm{MJ} \cdot \mathrm{kg}^{-1}, 17,94 \mathrm{MJ} \cdot \mathrm{kg}^{-1}, 15,03 \mathrm{MJ} \cdot \mathrm{kg}^{-1}$, a wartość opałowa $18,09 \mathrm{MJ} \cdot \mathrm{kg}^{-1}, 16,28 \mathrm{MJ} \cdot \mathrm{kg}^{-1}, 13,16 \mathrm{MJ} \cdot \mathrm{kg}^{-1}$. Średnia zawartość popiołu badanej biomasy dla temperatur spalania $600^{\circ} \mathrm{C}$ i $815^{\circ} \mathrm{C}$ wynosiła odpowiednio $2,12 \%$ i $2,04 \%$. W analizowanej biomasie zawartość azotu określono na 1,57\%, węgla 43,87\% i wodoru $6,29 \%$.

Słowa kluczowe: biomasa, ciepło spalania, wartość opałowa, zawartość C, H, N 